\title{
Sing a song of difference: Connie Boswell and a discourse of disability in jazz
}

\section{LAURIE STRAS}

School of Humanities, University of Southampton, Highfield, Southampton SO17 1BF, UK

E-mail: l.a.stras@soton.ac.uk

\begin{abstract}
Although a wheelchair-user and permanently disabled through polio, the southern American singer Connie Boswell was one of radio and vaudeville's biggest stars in the 1930s. She and her sisters were a compelling force in American popular entertainment for the first half of the decade; and when the group split in 1936, Connie carried on a solo career in radio, recording, film and television for another twenty-five years. Connie's unique position as the only visibly disabled 'A-list' female popular entertainer for most of the twentieth century - and one whose voice, both physical and musical, shaped the sound of jazz and popular music-makes her an obvious focus for any study that links popular music and disability. This essay is concerned with how disability may have operated as a discourse about and within Connie's chosen medium, jazz; and how disability studies can illuminate why the ways in which difference is figured in her work, initially a source of anxiety, could have also been a significant reason for her success.
\end{abstract}

\section{Introduction}

Although a wheelchair-user and permanently disabled through polio, the southern American singer Connie Boswell was one of radio and vaudeville's biggest stars in the 1930s. As the Boswell Sisters, she and her sisters Martha and Vet (Figure 1) were a compelling force in American popular entertainment for the first half of the decade; and when the group split in 1936, Connie carried on a solo career in radio, recording, film and television for another twenty-five years. ${ }^{1}$ Their remarkable musicianship, unique singing style and ground-breaking arrangements fused 'blackness' and 'whiteness' in music; they were instrumental in the creation of a new popular idiom, and Connie was a fundamental agent in the construction of the female popular singer's voice. She was recognised as one of the most influential singers of her generation by both the media and her peers, her most ardent champions - Bing Crosby, Ella Fitzgerald - among the defining voices of twentiethcentury popular music. ${ }^{2}$ Arguably, the Boswell Sisters' involvement with the preeminent white swing musicians of their day - the Dorsey Brothers, Glenn Miller, Benny Goodman, Artie Shaw - had a profound effect on the development of the big band sound in the 1930s and 1940s (Von Schilling 2008). It is perhaps unsurprising, then, that New York's most powerful entertainment agent of the inter-war years, 


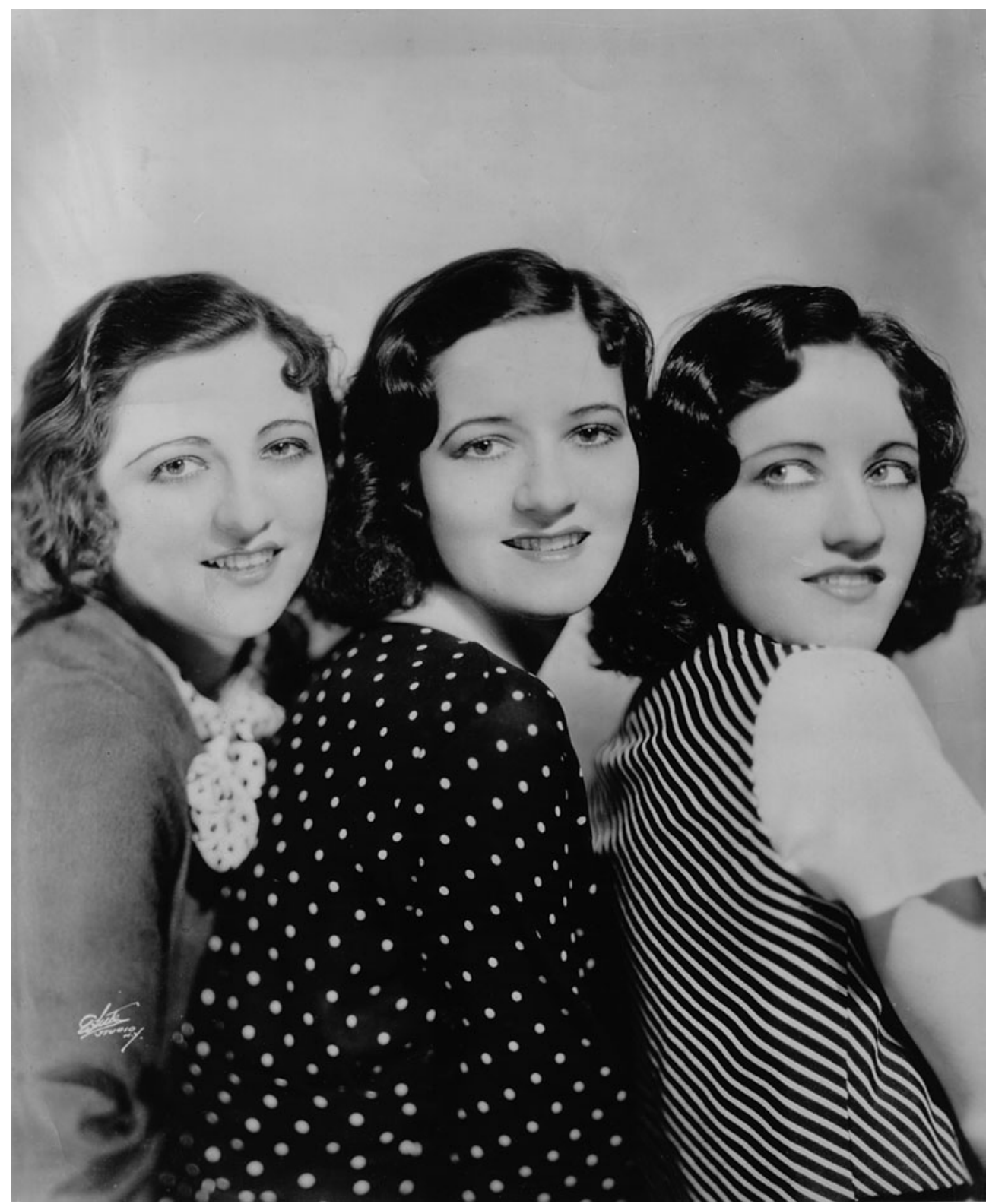

Figure 1. The Boswell Sisters in 1932: Martha, Helvetia (Vet) and Connie.

Cork O'Keefe, claimed they were the women who made 'real' jazz commercially viable, destigmatising the music and opening its appreciation to the wider American public. $^{3}$

Connie's unique position as the only visibly disabled 'A-list' female popular entertainer for most of the twentieth century - and one whose voice, both physical and musical, shaped the sound of jazz and popular music - makes her an obvious focus for any study that links popular music and disability. There is much to be said about the way her visual image was handled, the impact her mobility issues had on 
the progress of her career, and thus how her disability may have affected the longevity of her memory in the popular consciousness (see Stras 2008). However, this essay is concerned with how disability may have operated as a discourse about and within Connie's chosen medium, jazz; and how disability studies can illuminate why the ways in which difference is figured in her work, initially a source of anxiety, could have also been a significant reason for her success.

As musicology has embraced the scholarly discourses of difference - gender, sexuality, ethnicity, and race - we have become familiar with the ways in which markers of bodily difference have been used to describe music, musicians, musical qualities and musical events. Moreover, as these fields have matured, they have begun to establish an appropriate distance from their materiality: for example, we can accept that the social and hierarchical structures of gender have an impact on music far beyond the re-negotiation of the status of female composers (and, indeed, far greater than simply determining whether a cadence is 'feminine' or not); and we are happy to discuss the blackness of Dusty Springfield alongside the whiteness of the Supremes, acknowledging these qualities reside in the manipulation of signifiers within a discourse of race, rather than biological 'truths'. Yet a notion of 'disabled music' still remains predominantly rooted to the body, and in particular the body of the musician. A quick Internet search of the phrase brings up references to educational/cultural projects, such as the Drake Project in the UK, or political/ commercial pressure groups such as Leroy Moore's Krip-Hop Nation in the US. Even in this volume there is a strong focus on constructing narratives around and about disabled musicians (as I am doing in part here). We do not (yet) freely speak of or recognise music as something that can be disabled in and of itself. Partially, this could be the phase that the incorporation of disability studies into musicology is passing through: those who have engaged in disability studies for longer have recognised in their own disciplines that a process of maturation comes about that must, as part of the 'development of awareness, go through a hagiographic "great lives" chapter that reveals disability where it had been ignored, concealed or erased' (Longmore and Umansky 2001, pp. 15-17). Almost certainly it is also because we as yet lack abundant models for how the hermeneutics of disability studies can be applied to music, although the appearance in the last few years of seminal texts especially Joseph Straus's recent article in the Journal of the American Musicological Society (Straus 2006) and the edited volume Sounding Off: Theorizing Music and Disability (Lerner and Straus 2006) - have opened the doors for a more abstractly critical stage.

Like gender or race, disability is a discourse, a way of talking about and constructing the world: what is 'normal' and what is 'abnormal'; what marks something out as different and what it is different from. And as with gender or race, the parameters can be described in both biological and social terms. The biological, or medical, model equates normality both with health, and with a lack of substantial variation: disabilities are then defined as 'those variations in the structure, function and workings of bodies which ... are medically defined as significant abnormalities or pathologies' (Thomas 1999, p. 8). The social model is more concerned with the consequences of variation; that is, how that variation impinges upon or impairs ability. It encourages impairment to be viewed contextually; disability is then defined as a construction, the result of social barriers or restrictions experienced by the impaired person. ${ }^{4}$ For music to be disabled, then, it must either be functionally or aesthetically impaired; in other words, it must be unable to do what music is 
supposed to do, or it must be recognisably varied in a way that is deemed disadvantageous by the listener.

Again like gender and race, the language of disability has historical correlations with the language of censure. Since the medical model prevailed as the primary determinant of disability until relatively recently, that which was dangerous, defective, subversive, repugnant or corrupting might also be described in terms of a disability: lame, crippling, idiot, retarded, freakish, monstrous, crooked. Moreover, the dark side of 'variation' shared a vocabulary with that which was diseased and that which was dangerous: deformed, perverted, degenerate, abominable, unnatural, deviant, abnormal, aberrant, malignant. These associations are so commonplace that we no longer consciously interrogate them, and 'disabled' descriptors are generally used unintentionally with their broader meanings divorced from their bodily origins. Yet in the early twentieth century, jazz was condemned in explicitly pathological terms, the metaphors expounded to leave the reader or listener in no doubt of the connotations. Clear associations between jazz and disability were expressed by sociologists, physicians, music critics and musicians, and were promulgated in both the specialist and popular press. Even when trying to express a balanced (or at least non-committal) view, one sociologist resorts to medical terminology in a hope of portraying jazz as 'curable'. ${ }^{5}$ In the 1920s and 1930s, jazz was indeed 'disabled music', considered by many to be aesthetically and functionally impaired to the point that it not only served no purpose, but also was an active agent of medical and social disorder. ${ }^{6}$

Most commonly, jazz and its consumption were seen as both the origin and the product of mental or 'nervous' disorder, but they were also blamed for a range of both specific and unspecified physical symptoms. In July 1931, the Middlesborough Daily News reported a case of a woman being threatened with a 'sanity test' because of her late-night radio listening. . Pregnant women were warned that 'jazz mania' could lead to foetal mortality or deformity. ${ }^{8}$ In themselves, these reports do not suggest that jazz is impaired music. However, occasionally jazz's degenerative effects are compared with either benign or positive effects of other kinds of music consumption or participation, and here we begin to understand jazz as a form of music that is not fulfilling a proper role or purpose. Most obviously, jazz dance was portrayed as a physical hazard, acting on the body in a way that leaves it distorted by comparison to the effects of 'classical' dance.' But, according to a media medic, with the added import of jazz music, not only was it 'unhygienic' and unwholesome by comparison to 'polite' dancing, but it also could 'break down the moral restraints and lead to deplorable disasters'. ${ }^{10}$ 'Regular' music was portrayed, true to its Shakespearean reputation, as having a calming effect on the insane, whereas 'the effect of jazz on the normal brain produces an atrophied condition on the brain cells of conception, until very frequently those under the demoralizing influence of the persistent use of syncopation, combined with inharmonic partial tones, are actually incapable of distinguishing between good and evil, between right and wrong' (Walser 1999, p. 35). ${ }^{11}$ In another syndicated column, Midwestern readers were advised of the need for 'good' music to counteract the potential harm done to 'human nerve tissues' by jazz's 'perverted organization of sound'. ${ }^{12}$

In a two-part symposium issued in August and September 1924, The Etude published responses to the question, 'Where is Jazz leading America?', garnered from composers, teachers and conductors from all points along the classical-popular spectrum (Walser 1999, pp.41-54). Many of the opinions expressed echo the 
pathological and disabling concerns of the popular press, but the correlation is extended into describing musical events:

Jazz is to real music what the caricature is to the portrait. The caricature may be clever, but it aims at distortion of line and feature in order to make its point; similarly, jazz may be clever but its effects are made by exaggeration, distortion, and vulgarisms ... We can only hope that sanity and the love of the beautiful will help to set the world right again and that music will resume its proper mission of beautifying life instead of burlesquing it.

Like many things it proved very infectious and soon the whole world was inoculated.

It is entirely contrary to natural laws to syncopate, and only man does it ... When a baby does not cry rhythmically a doctor or a mother immediately realizes that something is seriously the matter with the child. When the wrong beat is accented there is an actual physical effect on the hearer, for a law is being broken ... [Jazz] fitted a hysterical period when the times were out of joint and a frenzied world sought surcease from mental agony in a mad outbreak of physical gymnastics... The violinist caught the germ and debased his instrument through the most flagrant musical indecencies. We had for orchestras a bunch of acrobatic maniacs ...

As a matter of fact, Jazz is a development of the rhythmical side of music, which is the most vital factor in music, but which in many ways may be considered somewhat of a negative virtue. It is taken for granted that a normal, healthy man will have a good heart beat; and it is taken for granted that good music will have rhythmic vitality and variety. / But good music must surely have many other qualities, such as melodic outline, deep emotional appeal, sublimity and ideality; and if the best that we can say of Jazz is that it is exciting, it seems to me that many of the highest attributes of music are left out.

This jazz epidemic has also had its degenerating effect on the popular songs of the day. In fact, nearly every piece of dance music we now hear is a rehash of these often vulgar songs ... 'Jazz' has created a 'malarious' atmosphere in the musical world. It is abnormal. The air needs clarifying! ${ }^{13}$

In the 1920s, more than ever before, disability was seen not just as a product of being 'born bad', or the outcome of divine retribution on the sinner or the sinner's progeny. The steadily increasing numbers of people surviving disease and industrial accidents and the vast influx of disabled veterans returning after the 1914-18 war made disability more prevalent and visible than it had been in the previous century. ${ }^{14}$ Moreover, this 'new' disabled population was made up of those who had become disabled rather than having been born disabled, thereby ensuring that disability was constructed as degeneration, deviation and loss at least as much as, if not more than, difference or lack. The quotes above show that jazz - at least when viewed negatively, and particularly when performed/appreciated by whites - was perceived as a deviation or distortion of something otherwise good and 'healthy'. ${ }^{15}$

Connie Boswell and her sisters began performing as a harmony trio in the middle of the 1920s, gaining recognition first locally in their hometown of New Orleans. They arrived in California just weeks after the stock market crash of October 1929; for the next year they grafted on radio sustaining slots and movie 'side-miking' in San Francisco and Los Angeles, before moving to New York in November 1930 after landing their first national broadcast contract with NBC. Once established as national stars, criticism of the sisters seems to have been rare, but during their first year of regular broadcasting in California, their station employers received letters of opprobrium from outraged listeners voicing disapproval of the sisters' new and unusual arranging and singing styles (McCain 2001). One read:

Why don't you choke those Boswell Sisters? How wonderful it would be if they sang just one song like it was written. Really when they get through murdering it, one can never recognize the original. 
Another purported to speak for the writer's whole social circle:

But please, please, if you are going to keep those Boswell Sisters tell them to change their stuff and quit that squawking and harmonize a tune. All my friends say the same thing. They call them 'savage chanters' and tune them out. ${ }^{16}$

These listeners saw the song - its melody and harmony - as something that should not be altered, at least not to the extent to which the Boswells went in their extravagant arrangements. The first, with particular allusions to bodily disorder, refers to 'murder' and complains that the music is disfigured, unrecognisable; the second suggests that the sisters' vocalising was something other than singing, and (to echo a phrase from one of the newspaper articles previously quoted) their 'perverted organization of sound' was something other than harmony. To these listeners, the Boswells' music was aesthetically and functionally impaired.

Soon after the girls moved to New York, they signed recording contracts with Brunswick, overseen by the man who became Decca's legendary first producer, Jack Kapp. Kapp was a forceful personality, and many musicians voiced discomfort with his overbearing, and perhaps none too sophisticated, artistic control, but his ear for the popular made Brunswick and then Decca commercial successes in the most hostile of financial climates. Kapp's golden rule, often quoted and reputedly writ large in the recording studio, was 'Where's the melody?' (Giddins 2001, p. 367). From the start, the Boswells must have found this very difficult; after their first Brunswick session, so the anecdote runs, the hapless composer of 'Whad'ja Do To Me?' complained bitterly, 'Whad'ja do to my song?' (Friedwald 1996, p. 169). The creative musical excursions of jazz improvisation clearly made Kapp nervous, and while he recognised and valued the Boswells' imagination, he exerted his own strict quality control on Brunswick's (and later Decca's) releases; sometimes songs were completely rearranged and re-recorded weeks later, presumably because Kapp found their ideas uncommercial. ${ }^{17}$

One such arrangement - for which there are significantly different versions extant - is their treatment of Sammy Fain's 'Was That The Human Thing To Do?', recorded by the Boswells and the Dorsey Brothers' Orchestra first on 5 February 1932, then again on 19 February. Coincidentally, perhaps, the song's lyrics turn on a conceit of inhumanity (and insanity). The Boswells were the second Brunswick group to wax the tune by a matter of days; Kapp may have been looking to capitalise on the success of Benny Kreuger's dance-band version (which went to Number 6 in the Billboard charts) by a near simultaneous release by the Sisters. One might reasonably expect the Boswells' arrangements to differ substantially from the other bands', simply because the Boswells never approached tunes from the viewpoint of a dance orchestra - they performed exclusively on radio and in vaudeville, so their priorities were different, allowing them to manipulate their material freely. However, even in comparison to white dance music's most adventurous arrangers, such as Bill Challis, who provided continuous variety in terms of orchestration, melodies, chord substitutions and key changes, the Boswells took greater liberties, regularly changing style, tempi, modality, lyrics, time signatures and voicings (both instrumental and vocal) to create unexpected textures and effects.

The Boswells' first version of the tune (hereafter Version 1 - see Example 1) shows the Boswell imagination at full tilt, responding to both the melancholy and the sinister in the lyrics. It begins with two bars of Jimmy Dorsey's clarinet, a free 
solo in the chalumeau register, which leads into a slow three-part vocal re-harmonisation of the verse (A). Breaking into a relaxed foxtrot tempo, Connie sings the entirety of the chorus as a solo (B), swinging the quavers hard and sitting far behind the beat. Slipping through a semitone, the next section introduces a slower, eerie minor march (C), which accompanies a chordal recitation of the lyrics right at the lowest extreme of the sisters' ranges. A bending parallel ornament in the voices highlights the off-beat, and a mocking break in the instruments at bar 69 makes full use of Dixieland-styled slides in the violins and trombone. Connie ends the section with a bluesy interpolation to replace the middle eight, but then Tommy Dorsey's trombone overlaps into the final eight, which returns to the slow tempo of the beginning. Connie takes the first four bars of this 'coda' in a torch-song style, and the sisters join her for a freely declaimed harmonisation of the last four bars.

In what appears to have been a test release (perhaps because Kapp was unsure of how well it would be received), Version 1 was released in Canada, but nowhere else, together with 'Put that Sun Back in the Sky' on the A side. Two weeks later, the sisters were back in the studio with the Dorseys recording both songs again, the arrangements having been reworked. 'Was That the Human Thing to Do?' is the more altered arrangement (hereafter Version 2), pieced together from sections of the first in a different order and at new tempi, with new interpolations and more freedom for the sidemen to participate. A four-bar introduction in the horns proceeds immediately into a solo chorus for Connie, equivalent to section (B); at around $150 \mathrm{bpm}$, the tempo is faster than any in Version 1 (and matching that of Kreuger's version). Her performance of the title line this time keeps the original shape of the tune, rising a fifth rather than falling a fourth at 'thing'. The chorus complete, a short break ending in a clarinet solo (an octave higher than in Version 1) leads into the verse section (A), this time performed at about $100 \mathrm{bpm}$. This segues sharply, via a solo guitar modulation into D major, back into the chorus at the original tempo of $150 \mathrm{bpm}$, providing an opportunity for eight bars each of clarinet and trumpet solo. This is followed by the minor section $(C)$ but with no change in tempo. The instrumental parts differ slightly: the snare solo disappears, and the fanfare at bar 47 is replaced by a staccato arpeggio figure in clarinet and violin (Example 2) that repeats pianissimo over the vocal recitation. The section, and indeed the rest of the arrangement, finishes exactly as in Version 1, with identical trombone solos over the vocal coda (D). Version 2 was pressed in two different takes from the same session, one used for general release in America and Spain, the other released only by Brunswick's subsidiaries in France and Germany.

Although the two arrangements are made up of nearly the same elements, and with almost the same number of tempo changes, the undoubted weirdness of Version 1 is considerably tamed in Version 2, particularly with relation to the minor march. The vocal bending ornament becomes almost a mordent at the new tempo, and the mocking Dixieland break, which at the slower speed tinges the whole section with a jazz funeral feel, loses its glissando flourish and stomp - and therefore most of its character - at speed. The placement of the verse in the middle of the arrangement, even with its slower tempo, again aligns it with Kreuger's version.

Version 1 is by no means the most outlandish of the Boswells' arrangements, but the circumstances of its release and apparent withdrawal show that Kapp - who was by all accounts a great servant of popular taste - felt that it was too far beyond the pale to risk general release. Many years later, Connie said of Kapp, 'Jack was a wonderful guy, he was a terrific commercial man. When he first started hearing us, 

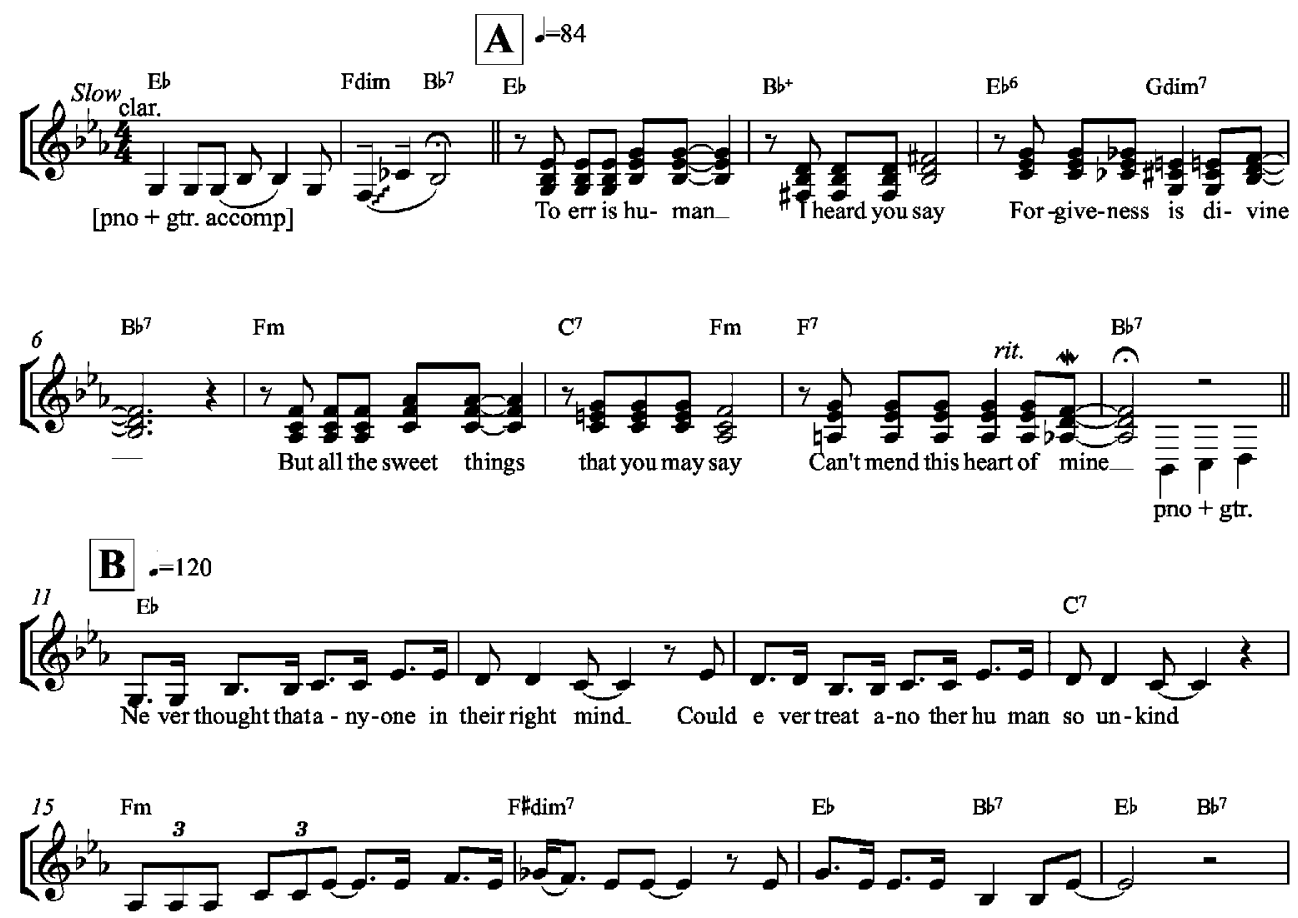

Did-n't you sneak a-way and leave a note be-hind? Was that the hu manthing to do? -
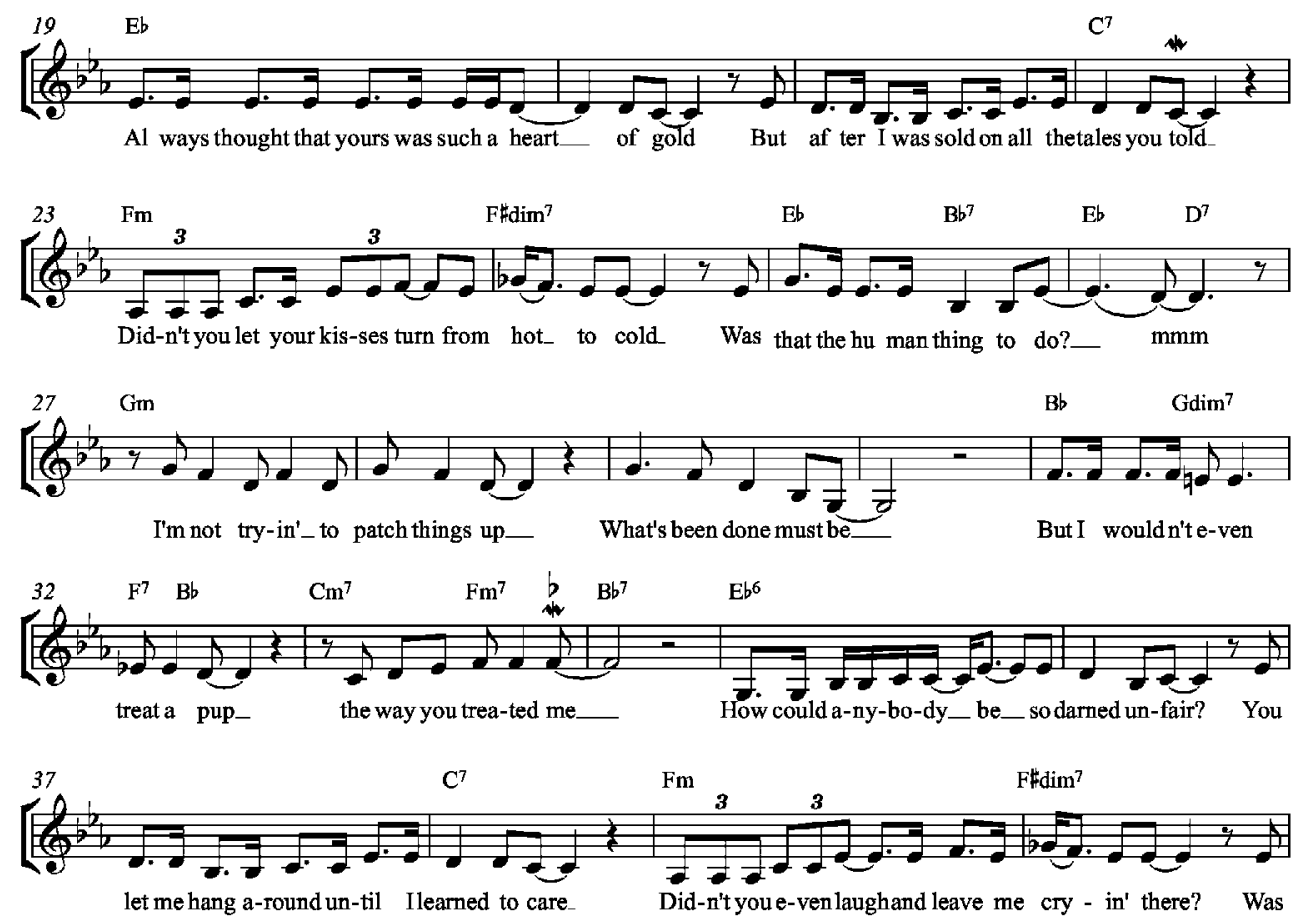

Example 1.'Was That the Human Thing to Do?' (Sammy Fain/Joe Young), The Boswell Sisters acc. The Dorsey Brothers' Orchestra, BrCa 6257, 1932. 

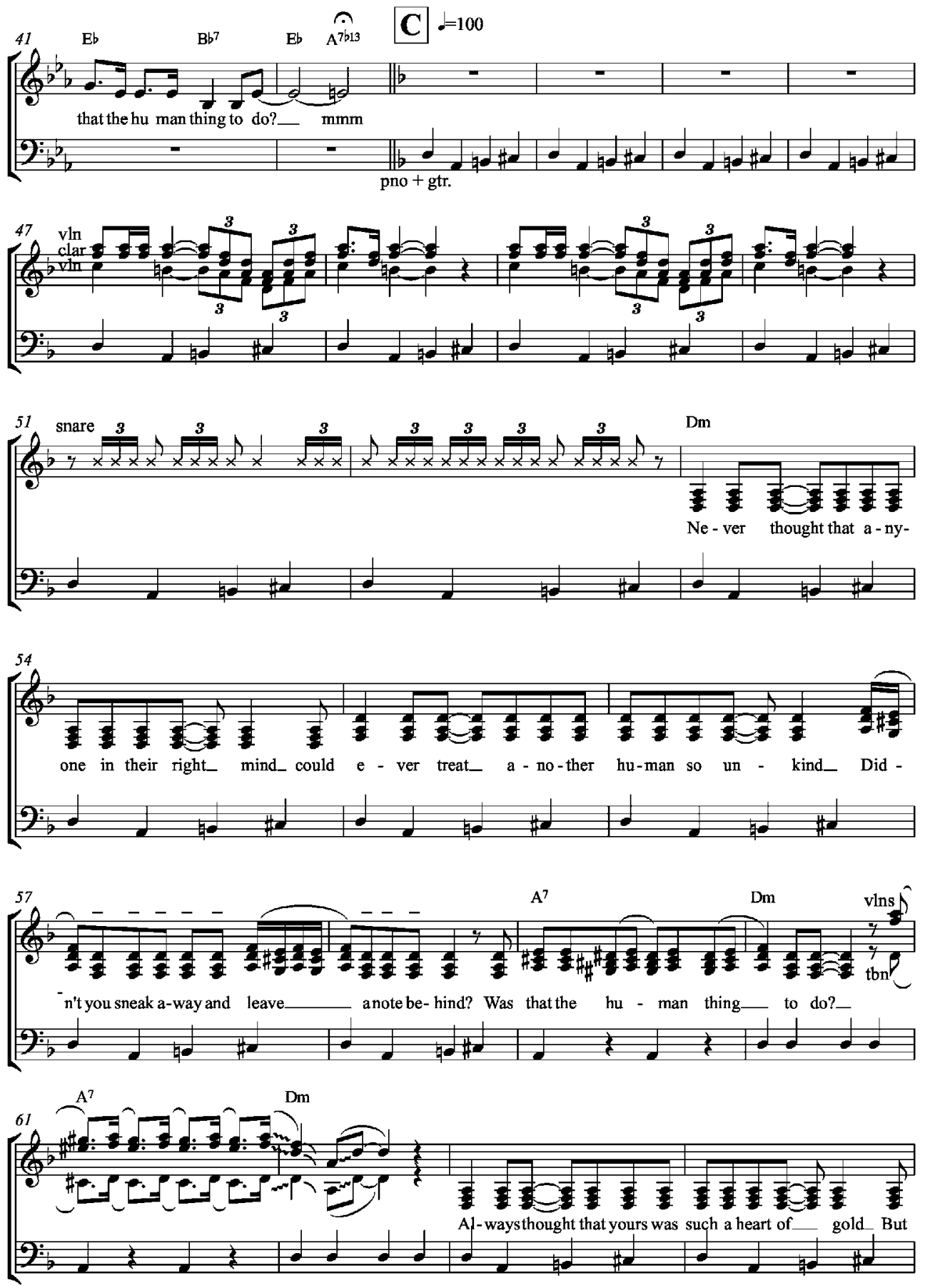

Ex. 1 cont. 

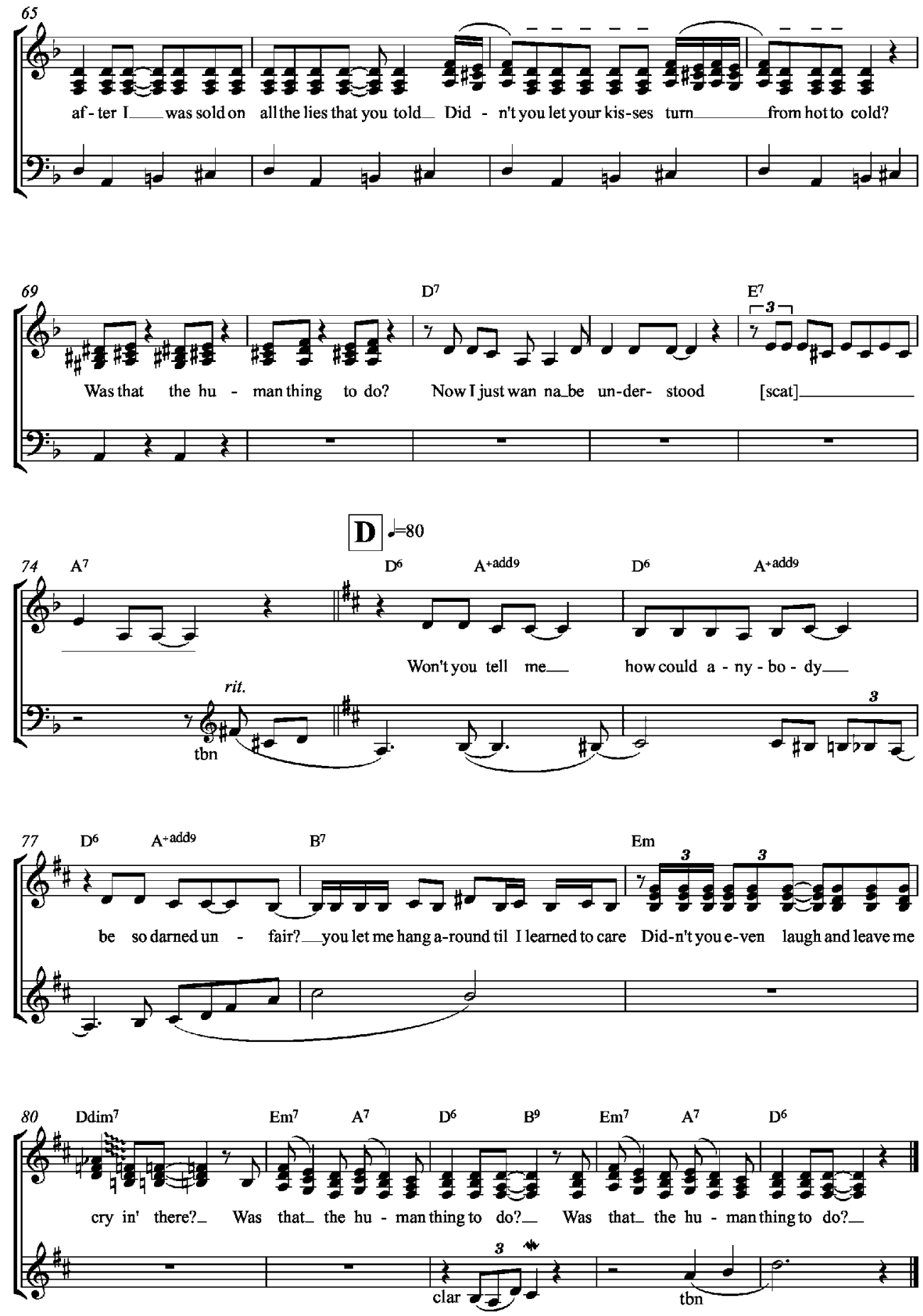

Ex. 1 cont. 


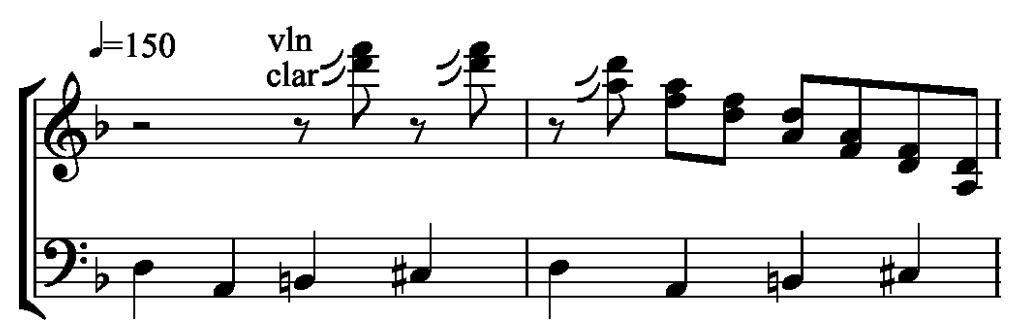

Example 2. 'Was That the Human Thing to Do?', Version 2 (Br6257), substitute figure.

he liked us, but he wanted to rearrange us. He wanted us to sing differently, to stick a little closer to the melody ... In many choruses I did the full melody, so that you got the beauty of the melody itself. But many times a melody would be good, and when the three of us put it together it wouldn't sound as good as when we kept the lyric but changed the melody' (Friedwald 1996, p. 172). The minor march may have been a step too far, for not only did it do away with the melody, it also eschewed even the rhythmic vigour of a dance tempo. Recalling the remarks of the Harvard professor made eight years previously in The Etude, this passage did not even have a 'normal, healthy ... heart beat'.

The objections of Kapp and the Boswells' early California audience to the way the sisters treated some of their material are similar to the earlier tirades of the 1920s; but rather than criticising the sisters' music for not fulfilling a moral purpose, they complain that it does not faithfully deliver what the composer intended, or accurately portray something familiar to the audience in a way that is recognisable to them - so revealing yet again an attitude that saw jazz as aesthetic disfigurement and functional impairment. Yet the gap between the complaints of the mid-1920s worthies in The Etude and those of Kapp and the 1930 Californian radio audience is related to not just musical function, but also the difference between instruments and the voice. Instrumental jazz, particularly through the medium of the dance band, had become a commonplace for radio audiences by the beginning of the 1930s, representing at least three-quarters of radio programming (Leonard 1964, p. 92). Vocalists had been integral to dance band recordings throughout the 1920s, and were incorporated into arrangements in a standard fashion (instrumental chorus / optional verse, instrumental or vocal / vocal chorus / instrumental chorus) but they had little musical importance and were frequently uncredited. Hoagy Carmichael's character Smoke Willoughby in the 1950s film, Young Man with a Horn, claimed they were only there as a commercial imperative, so that the little girls who bought the records could learn the words (Friedwald 1996, p. 51). Vocalists were there to present the song as it was written, establishing the musical norm. In his essay 'Normalizing the abnormal', Joseph Straus establishes that nineteenth- and twentieth-century (classical) musical thought was frequently expressed in terms that can be equated to the language of disability, particularly the project of curing or overcoming disadvantage - regaining wholeness of form, correcting imbalance, 'curing' dissonance (Straus 2006, pp. 152-5). The basic dance band arrangement violates this scheme of a progression towards wholeness, for the final instrumental chorus after the vocal is usually the locus for the majority of the extemporisation or alteration. All the more important, then, that the singer be the conduit of an accurate rendition of the tune. Even those artists like Cliff Edwards, and later Louis Armstrong and Cab 
Calloway, who developed scat singing as part of a transliteration of the patterns of instrumental jazz, began with a 'straight' performance of the song before tampering with it in any but the mildest fashion. The Boswells' arrangements, especially in their early years, are likely to betray these conventions even from the opening bars, and the sisters as singers could be heard to be abrogating their responsibilities to both the songs and their audience; they do not function as singers should.

If some regarded jazz as dysfunctional within the context of music in general, we can see how the Boswells' music might further be considered to be dysfunctional within the context of the vocal performance of popular songs, so compounding its 'disability' in both formal and aesthetic function. And yet the Boswells grew in popularity astonishingly quickly, eventually rising to what one music magazine called, 'an enviable position in the entertainment world, that of a novelty which has become a standard of entertainment and a standard of comparison' ${ }^{18}$ Certainly they inspired many girl harmony trios to form in their wake; and although these groups had also to negotiate the boundaries of popular taste, by virtue of their imitations they may have helped naturalise the Boswell style into something universally (or near universally) palatable. ${ }^{19}$ While imitator groups - including the Andrew Sisters - were able to approximate the Boswells' tight blend and even mimic some of their musical gestures, their arrangements were blander and more regular, lacking the Boswells' characteristic invention and musicianship. ${ }^{20}$ So how did the Boswells make that journey from 'novelty' to 'standard'? How / why did their 'disabled music' become so popular?

Disability studies can provide several models for examining this question, depending on whether we regard the Boswells' music as disabled in and of itself, as a representation of disability, or as the work of a disabled musician: all these approaches originate from the work of Rosemarie Garland-Thomson in her analyses of disability as it is figured in both words and images in American culture. Thomson's primary concern is with visible disabilities, but I would maintain that it holds true for perceptible disabilities, in a wider sense: the invisible disability of a speech disorder becomes evident as soon as the disabled person begins to communicate with another, and 'disabled music' would be analogous to this kind of impairment. Garland-Thomson describes the initial contact between a disabled person and a non-disabled person:

The interaction is usually strained because the nondisabled person may feel fear, pity, fascination, repulsion or merely surprise; [...] a nondisabled person often does not know how to act toward a disabled person ... Perhaps most destructive to the potential for continuing relations is the normate's frequent assumption that a disability cancels out other qualities, reducing the complex person to a single attribute. This uncertainty and discord make the encounter especially stressful for the nondisabled person unaccustomed to disabled people. (Garland-Thomson 1997, p. 12)

Garland-Thomson explains that the disabled person must therefore develop additional means in order 'to be granted fully human status':

In other words, disabled people must use charm, intimidation, ardor, deference, humor, or entertainment to relieve nondisabled people of their discomfort. Those of us with disabilities are supplicants and minstrels, striving to create valued representations of ourselves in our relations with the nondisabled majority ... If such efforts at reparation are successful, disabled people neutralize the initial stigma of disability so that relationships can be sustained and deepened. Only then can other aspects of personhood emerge and expand the initial focus so that the relationship becomes more comfortable, more broadly based, and less affected by the disability. (ibid., p. 13) 
Certainly the Boswell Sisters' arrangements and especially their early records, whilst disruptive of the norm, are charming, ardent, entertaining and, above all, humorous; if these are tactics employed by disabled people in order gain acceptance, we can also recognise them as one of the means by which an audience comes to accept 'novelty'. 21

Elsewhere I have argued that it is no coincidence that the Boswells' rise to success coincided with the emergence of the Great Depression, and that their performance of blackness via southernness was integral to their appeal to an America battered by calamity and random misfortune (Stras 2007). But the humorous dislocution of their arrangements did not just mirror comedic practices from black vaudeville, it also effectively parodied the state of the nation: as the world was turned topsy-turvy, so was the song. The irreverence of the sisters' treatment of Depression anthems such as 'Life is Just a Bowl of Cherries' signals an acknowledgement - for both musicians and audience - that Tin Pan Alley's salve of chirpy songs provided only a desperately thin veneer of optimism. ${ }^{22}$ Garland-Thomson reminds us that Mikhail Bakhtin's grotesque and carnivalesque figures operate as 'extraordinary' - or disabled - bodies (Garland-Thomson 1997, p. 38); Bakhtin's own description of the operational environment for the grotesque serves as a vivid portrayal of the reality of American life as it broke down in the early 1930s: 'All ideological forms, that is, institutions, become hypocritical and false, while real life, denied any ideological directive, becomes crude and bestial' (Bakhtin 1981, p. 162). Against this background, grotesque figures 'grant the right not to understand, the right to confuse, to tease, to hyperbolize life'; as such, the Boswells' 'disabled music' perhaps gave voice to America's bewilderment at its sudden change, so making the unbearable bearable, the catastrophic comedic, and the abnormal acceptable. The music then functions as a disabled body in the way it interacts with the non-disabled audience, using qualities of action - charm, humour - to gain acceptance and approval, and moreover to permit the listener to embrace abnormality in his or her own life, or as Bakhtin puts it, 'the right to be "other" in this world' (ibid., p. 159).

There is an important qualification, however, to be made when considering the Boswells' music - and indeed jazz as a whole - as a body, inasmuch as its materiality is either fixed, as in a recording, or ephemeral, as it would have been in a live performance or radio broadcast: it is not, except in the most metaphorical sense as a corpus, a living, flexible and changing being. The Boswells' arrangements are as much representations or images of a single disabled entity (jazz) or entities (disfigured songs) as they are the bodies themselves. Images of disability 'define the norm by picturing the deviant' and as such 'act as rhetorical figures that have power to elicit a response from the viewer' (Garland-Thomson 2001, pp. 336-9). In her study of disability portrayed in popular photography, Garland-Thomson proposes a 'taxonomy of four primary visual rhetorics of disability: the wondrous, the sentimental, the exotic, and the realistic' (ibid., p. 339):

the wondrous mode directs the viewer to look up in awe of difference; the sentimental mode instructs the spectator to look down with benevolence; the exotic mode coaches the observer to look across a wide expanse toward an alien object; and the realistic mode suggests that the onlooker align with the object of scrutiny. (ibid., p. 346)

We can recognise instantly that the first three modes operate across a distance, separating the viewer from the viewed, but the fourth is designed to minimise the gap between them; in other words, wonder, sentiment and exoticism are modes of 
difference, while realism is a mode of sameness. Garland-Thomson goes on to stress that, 'in representing disability, the visualisation of impairment, never the functional experience of it, defines the category of disability. In this sense, disability exists for the viewer to recognise and contemplate, not to express the effect it has on the person with a disability' (ibid., p.346). So with representations, we are more concerned with the effect on the beholder than we are with the function of the beheld.

Garland-Thomson illustrates her four rhetorical modes with images drawn from popular photography: the wondrous mode is found in an image of a person rock-climbing in a wheelchair; the sentimental mode is invoked by a vintage March of Dimes poster which depicts a polio-stricken infant; the exotic mode is exemplified by nineteenth-century 'freak' photography, and the realistic mode by an official portrait of a contemporary disabled public servant. Garland-Thomson is careful to point out that the modes rarely occur in isolation; they most frequently are found in combination in a single image, so that a variety of responses may be elicited from the viewer. The cover of the July 1938 issue of Down Beat, which features Connie in her stage wheelchair (Figure 2), shows how this may occur: the wondrous is invoked by her clear status as a celebrity performer, as evidenced by her dress and the rhinestones on her wheelchair (she is a disabled popular entertainer, but she is not a star because she is disabled; she has heroically overcome her disability to do something that many non-disabled people could not do); the sentimental by the suggestion of unmerited suffering (how could such a beautiful woman be so impaired?); the exotic by the franknesss of the full shot of her wheelchair (the picture could easily not have included the wheels, but their inclusion arrests the eye once they are noticed - while stardom distances her from the public, her disability distances her from other stars); and the realistic by the way her disability is incorporated into the whole image (because her wheelchair is styled appropriately, her chair and gown complement each other rather than jarring together; her cheerful and animated expression draws attention away from the chair).

It is possible to equate the 'distancing' modes in a general sense to familiar aspects of jazz that use change or distortion to particular effect: wonder may be invoked by virtuosic delivery or improvisation that distort the song; free interpretation (ergo distortion) may be used to provoke an emotional/sentimental response sympathetic to the performer; and complex arrangements can alter the song into something wonderful and strange, fascinating the listener. Moreover, the first rhetoric of wonder can be seen to operate in the acceptance of much innovation in popular music, or indeed any other art form in which change may happen incrementally, through the introduction of something unfamiliar into a familiar context: 'by juxtaposing the singular (therefore strange) mark of impairment within a surrounding context of the expected (therefore familiar) the picture coaches the viewer to understand impairment as the exception rather than the rule' (GarlandThomson 2001, p. 351). The challenge represented by the impairment/novelty/ innovation is framed by 'normality', thereby both highlighting its strangeness and dissipating its danger, and so increasing its aesthetic, commercial or simple curiosity value. However, before thinking of more specific examples, we need to take care to recognise that Garland-Thomson's taxonomy relates to images of disabled people's bodies; transferring the analysis to musical images of musical 'bodies' is not without complications. Generally, human beings do not identify individually with musical works (although they may with the performer or composer, or with the feelings 


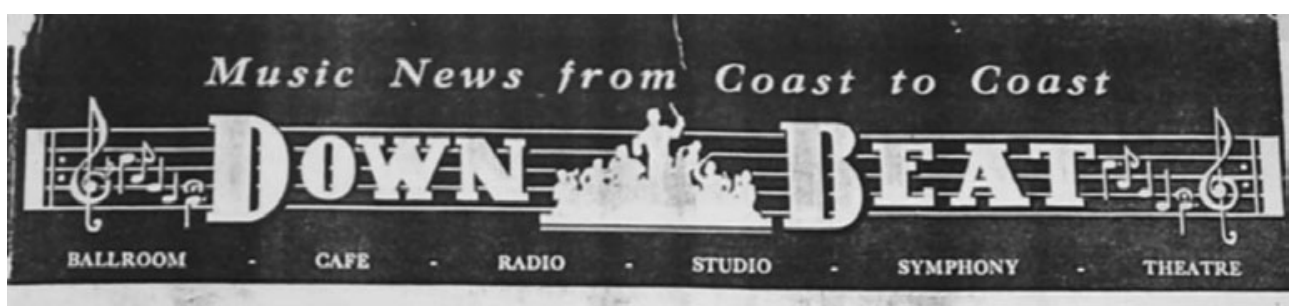

\section{I'M A SUCKER FOR BIG NAME BANDS! 年些}

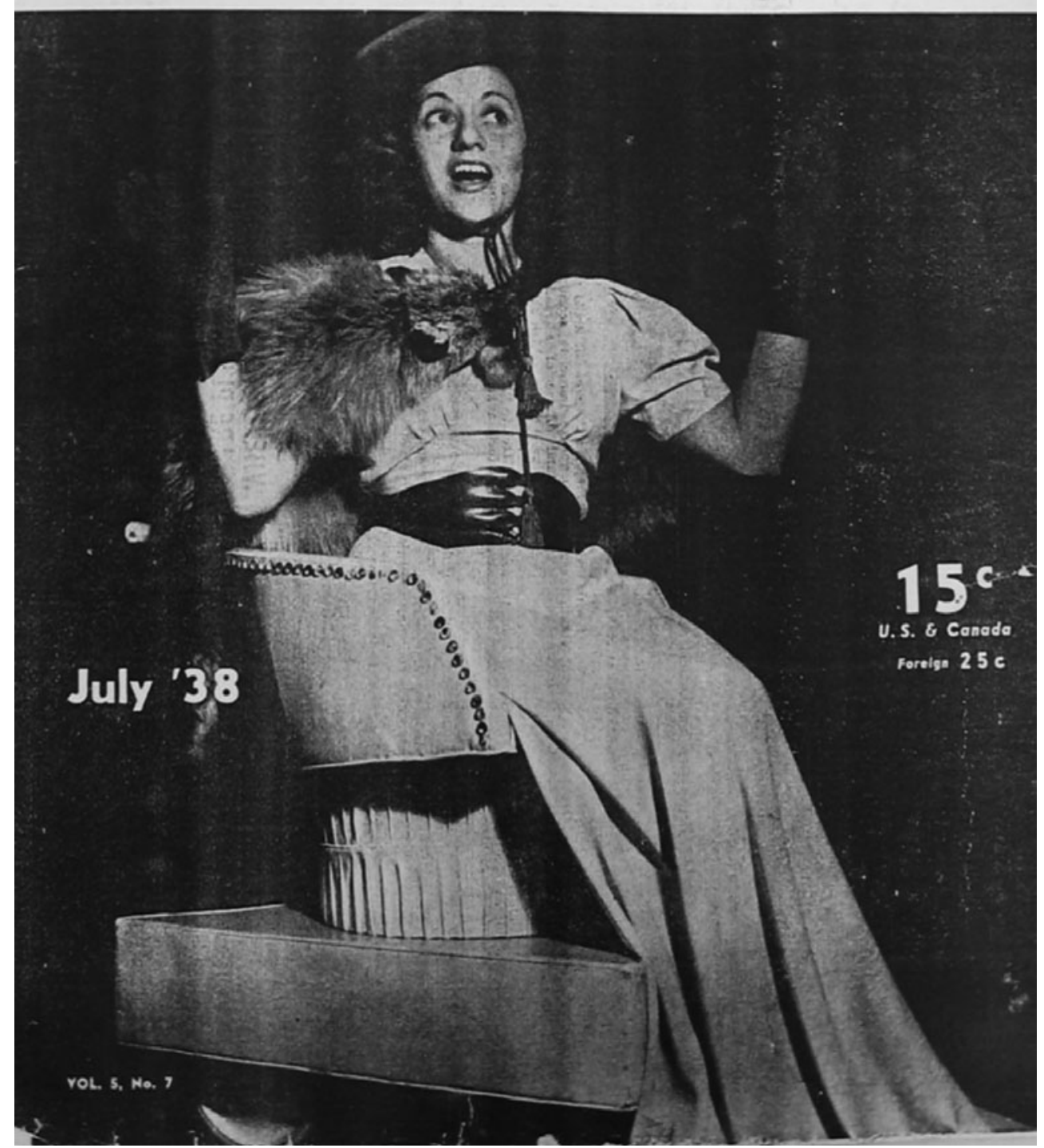

Figure 2. Cover, Down Beat, 5/7, July 1938, showing Boswell in her stage wheelchair. 
generated by the music in themselves), but musical representations of disability can be constructed to elicit some of the same effects as Garland-Thomson finds in her images. Furthermore, Garland-Thomson's rhetorics work concurrently - although it is possible to engineer or direct the initial reading sequence of a single visual image, the order in which a beholder then considers and reconsiders its elements is out of the control of the image-maker; in music, the order of events is entirely determined by the music-maker, so while a single element of the musical image may serve two or more modes simultaneously, the rhetorical register can also change in progression.

The Boswells' arrangement of 'Everybody Loves my Baby'23 (Example 3) was recorded five days after their second 'Was That the Human Thing to Do?' session, on 24 February 1932. The arrangement contains another complete song within it: 'Yes, Sir, That's my Baby'. It contains all of the signature devices that characterise and distinguish the Boswells' recordings: scat, both solo and three-part; instrumental imitation; 'Boswellese' gibberish; tempo changes; metre changes; major/minor juxtaposition; key change; interpolation of material from other sources. All three of Garland-Thomson's 'distancing' modes are at work in the arrangement, sometimes concurrently, sometimes individually. The first mode, the wondrous, occurs in the juxtaposition of the abnormal and the normal, in such a way that invoke[s] the extraordinariness of the disabled body in order to secure the ordinariness of the viewer' (Garland-Thomson 2001, p. 341). For example, the scat that replaces the middle eight in Connie's solo (bar 41) serves both to be extraordinary in its own right and to allow the return of the melody in bar 49 to 'recover' normality for the listener. $^{24}$

The second mode, the sentimental, appears at first not to be operative (or at least to be obscure), but its presence can be discerned through its effect on the listener. Garland-Thomson argues that the sentimental mode incorporates both infantilisation and the concept of 'cute', which position the viewer/listener in a hierarchy above the considered object. ${ }^{25}$ Disability is then experienced to be something that the beholder can normalise or patronise; at most the sentimental mode gives the beholder the agency to 'solve' disability, at least it allows him or her to feel superior to the disabled object. The 'Boswellese' performance of 'Yes, Sir, That's my Baby' (at C, bar 57) presents a puzzle to the listener in the form of words garbled by a childish play-language. ${ }^{26}$ In order to understand this section, the listener must recognise the tune through its melodic outline, hear the concatenation of banjo 'language' (the strum rhythm) and modified English, and then translate the lyrics, however subconsciously, as one translates the babble of a toddler learning to talk, or of children using 'speech disguise' (Crystal 1990, pp. 15-16). ${ }^{27}$ The listener therefore recovers normality for him- or herself from the fractured elements as they have been presented.

The third mode, the exotic, plays out at many levels in the arrangement, and perhaps some of the bewilderment engendered by the rapid shifts into and out of the gibberish middle section can be explained by the conflicting motives of the sentimental and the exotic. As Garland-Thomson states, 'The rhetoric of sentiment domesticates the disabled figure, making it familiar and comforting. In contrast, the visual rhetoric of the exotic traffics in the alien, the strange, and the distant ... The exotic demedicalizes, fascinates, seduces with exaggeration, and creates an often sensationalized, embellished alien' (Garland-Thomson 2001, pp. 356-8). Moreover, there is a kind of erotic charge and danger to the exotic that complements the 


\section{\lrcorner$=244$ tpt

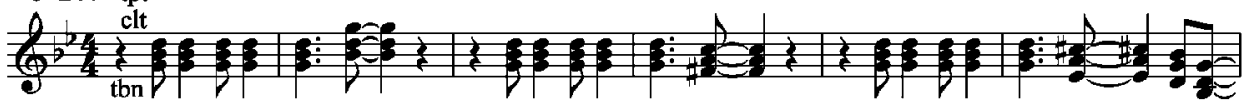
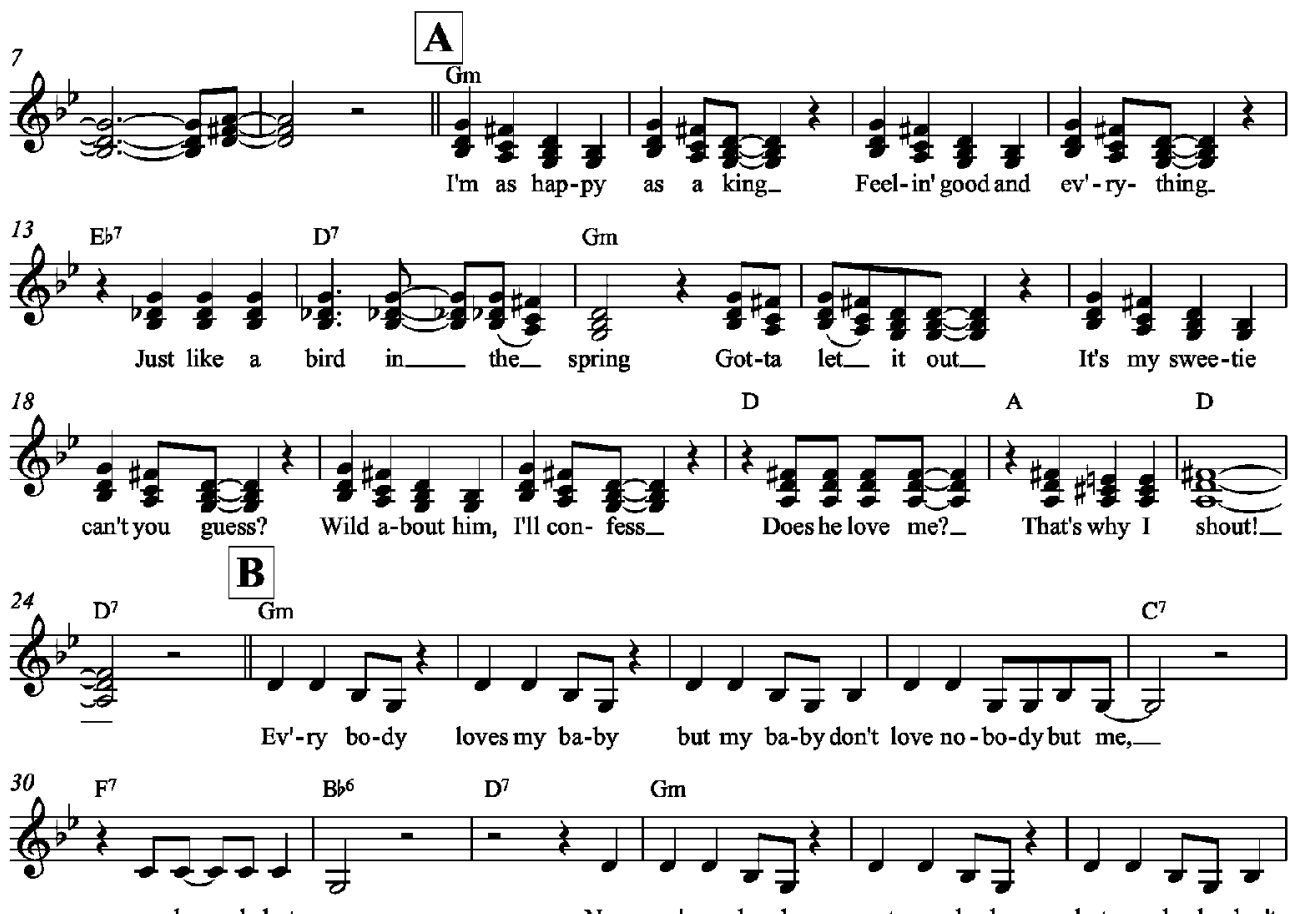
no-bo - dybut me

Now ev'-ry -bo-dy wants my ba-by but my ba-bydon't
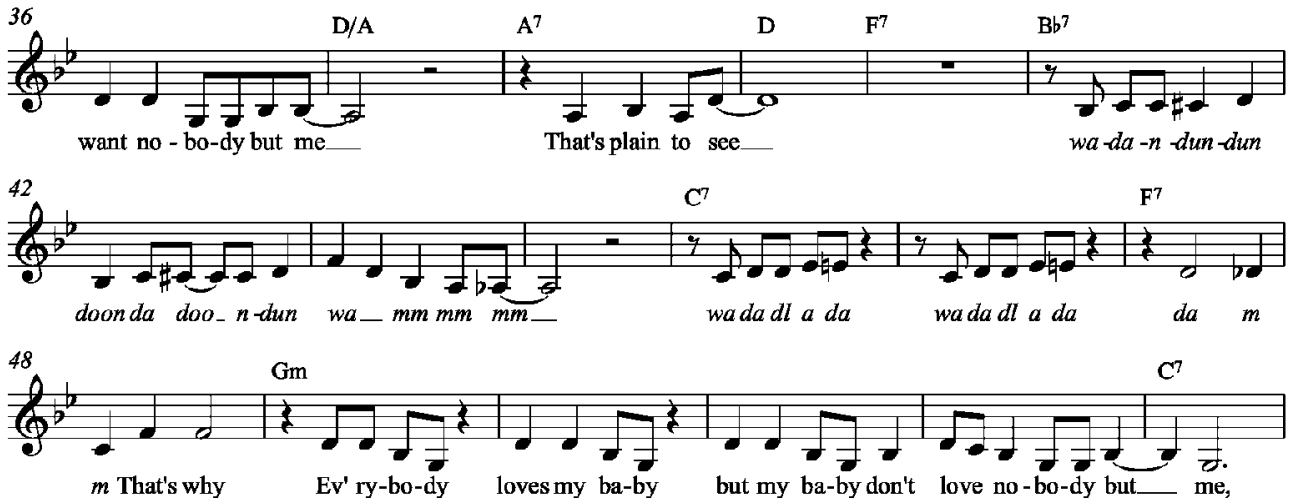
C $d=160$

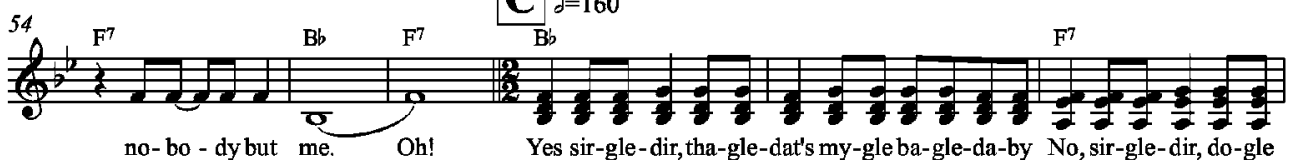

Example 3.'Everybody Loves my Baby' (Jack Palmer/Clarence Williams), The Boswell Sisters acc. The Dorsey Brothers' Orchestra, Br 6271, 1932. 

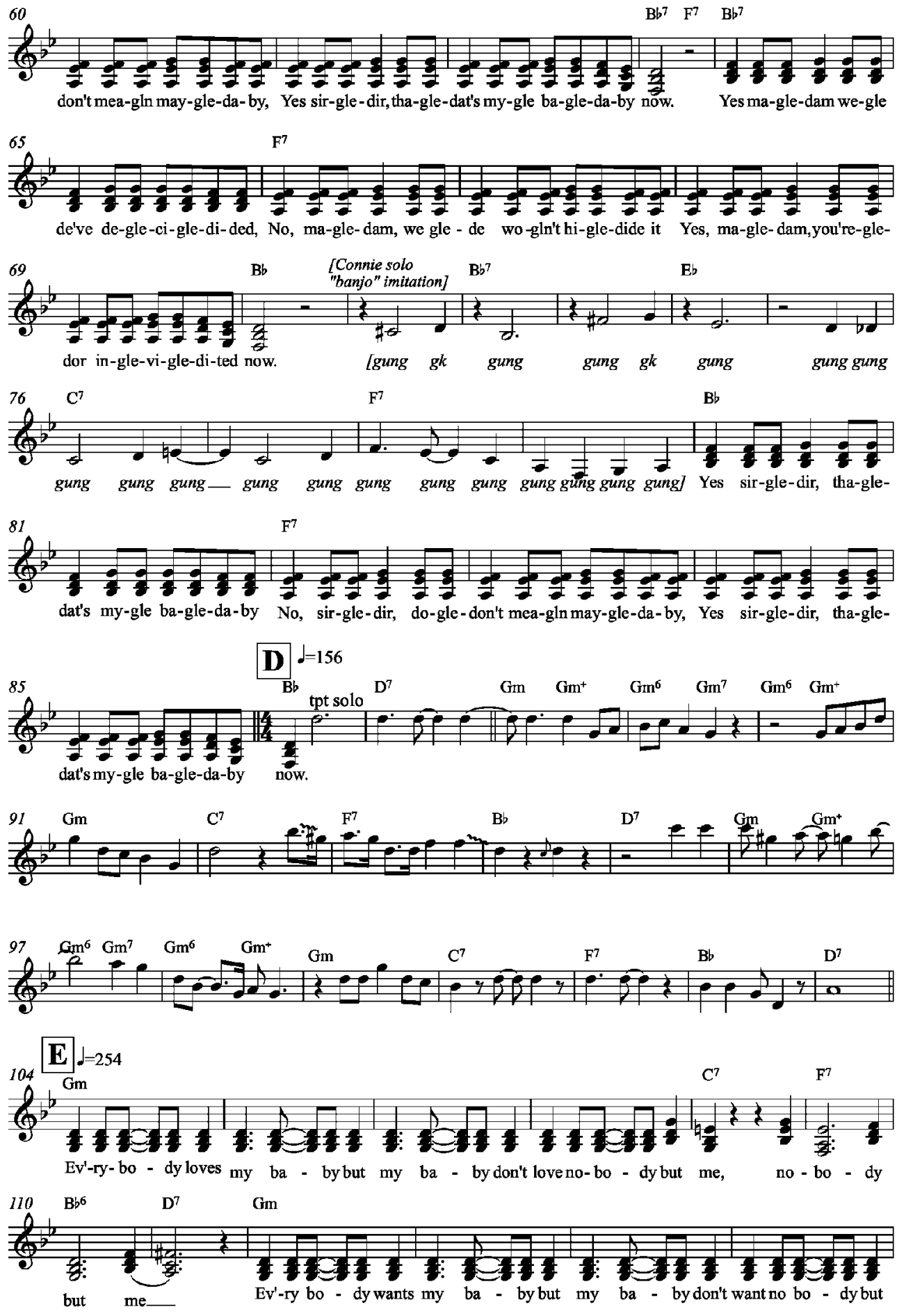

Ex. 3 cont. 

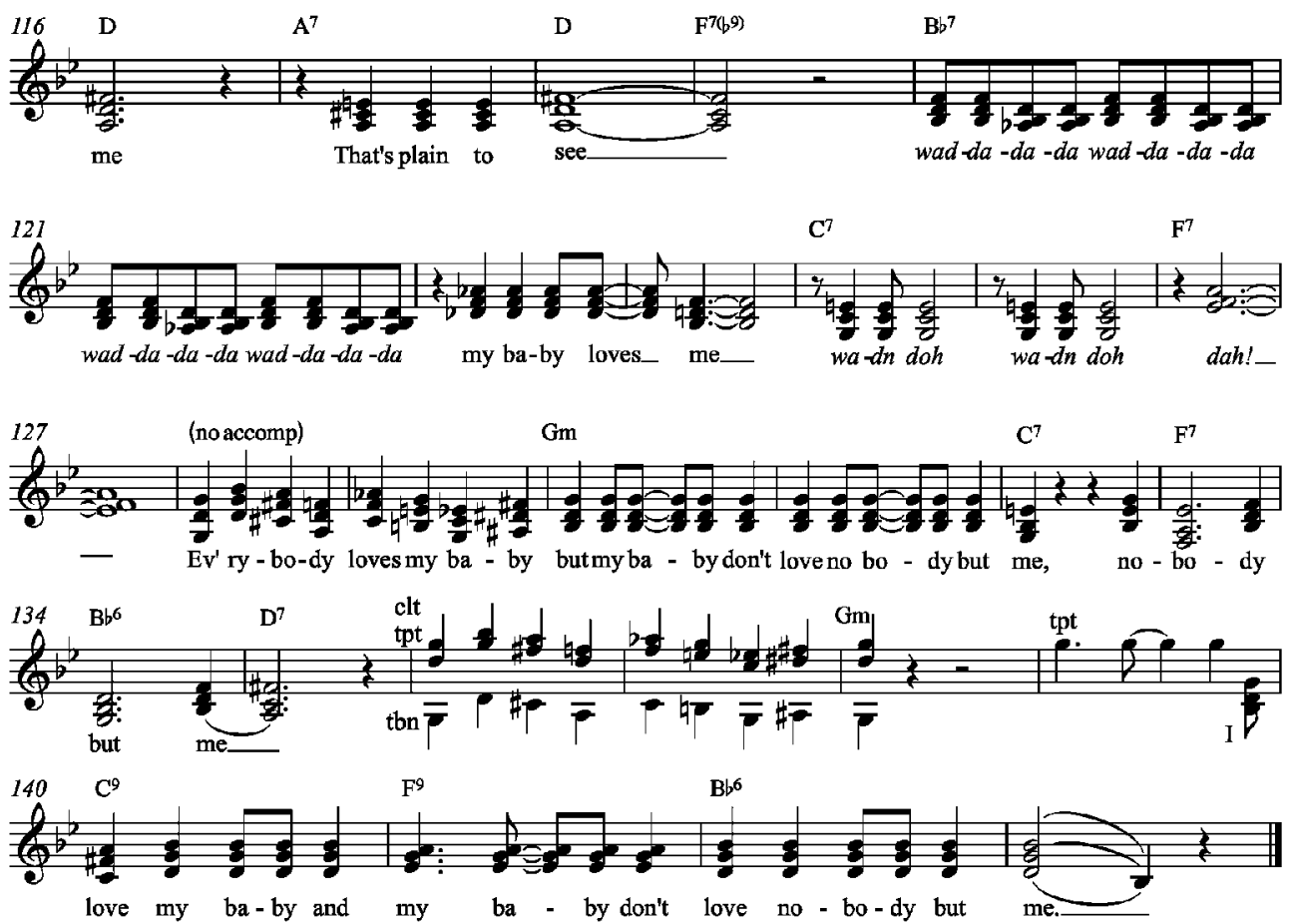

Ex. 3 cont.

wondrous, but instead of framing or contrasting abnormality with normality, the abnormality is displayed without reference to comfort. Sections D and E reintroduce the original tune, however drastically altered, and in no respect do they represent the 'normality' established in the opening chorus. The chords accompanying the slower trumpet solo introduce a chromatic creepiness (voiced in both piano and band in an off-beat vamp); the scrambling second-inversion chords at bar 128 (reiterated at bar 135) take this chromaticism to an extreme. The only thing that is reassuring about the distance that the exotic mode creates is that the object is indeed distant, so it may be observed for delight or amusement at a safe remove. ${ }^{28}$

So what of the fourth mode, the realistic? Garland-Thomson accords this mode the most positive outcomes, as it is the means whereby representations of disability can encourage identification and sameness, rather than difference. 'By depicting [the subject] as an ordinary person ... [the image] encourages viewers who consider themselves as either disabled or nondisabled to identify with [it] ... Such representations banish the strange and cultivate the ordinary, radically reimagining disability by installing people with disabilities in the realm of human commonality' (ibid., p. 370). I have already noted that in the 1920s, the jazz vocalist's job was primarily to introduce the song, unadorned; this showed it in its most marketable format (i.e. that which could be reproduced by the consumer). But by the time the Boswells started appearing on the radio and making records, the singer was beginning to assume a greater importance. Radio audiences, in particular, connected with singers in a way that they could not with instrumentalists, and they were able to do this because microphone technology had advanced to a point at which the human singing voice could be heard without the timbre-altering, diction-dulling effects of 
the megaphone. Paula Lockheart, in her study of the changes in singing fashions that accompanied this technological development, notes that audiences became very aware of singers' 'personalities' as they imagined them projected in their voices (Lockheart 2003). Allison McCracken goes further, charting the fantasy relationships listeners conjured with singers like Rudy Vallee and Bing Crosby, based entirely on the intimate connection they felt established with the singers' voices (McCracken 1999). I would suggest that this tendency towards identification occurred between all singers - including the Boswell Sisters - and their audiences, but that it was particularly Connie's solo work that encouraged the audience to identify with, and so accept, the modifications she wrought upon the tune. Although always aware that the Boswells are singers, the audience experiences an aesthetic shift when Connie sings solo passages - suddenly, and without warning, they are connected with a person.

Popular singing, particularly as it was developed by Connie and her peers, fulfils the realistic category. The rhythmic and melodic alteration of the formal structure of the song into the cadences of speech aids in entrainment between singer and audience, but identification comes through the 'telling'; it comes through the voice itself, not just the words. As with 'Was That the Human Thing to Do?', there is an alternative version of 'Everybody Loves my Baby' (this time a live performance, without a band, recorded in Schevinegen in 1935) with which to compare performances, and again Connie is much freer with the melody in this 'unsanctioned' version. Yet even in the recorded version, we are aware of the body in her voice, the slight rasp of the vocal folds, the edge on the tone and the pressure of her intercostal muscles as she extends into her upper range. In both versions, she takes a scat solo as an instrumental 'banjo' imitation, bars 71 through 79; in the live version, she also takes Section D as a solo, this time imitating the trumpet. Vocal trumpet imitations remained part of Connie's inventive palette for many years to come, but here we can imagine a specific purpose for them. We can see her trumpet imitations as a parody, or even an extension, of the craft of singer-instrumentalists such as Louis Armstrong, Valadia Snow or even Rudy Vallee. ${ }^{29}$ By incorporating jazz's characteristic instrumental improvisation into vocal performance, bypassing even the transliteration-cum-infantilisation of scat, she brings the disabled or disfigured song into focus as a wholly human, playful expression and experience. Reiterating Garland-Thomson's words, 'such representations banish the strange and cultivate the ordinary, radically reimagining disability by installing people with disabilities in the realm of human commonality'.

Having reflected on Connie's music as a potentially disabled form, and also as a representation of disability, it remains to consider it as the product of a disabled musician. We might wonder what impact Connie's mobility issues had on her ability to make music; certainly they were fundamental in determining the trajectory of her career, especially once the Sisters disbanded and she was left to forge ahead, in an industry that was rapidly changing from audial (radio and phonography) to visual (film and television) dominance (Stras 2008). We might marvel at the apparent power and size of her voice, given that she was reportedly tiny - no more than five feet tall and weighing no more than a hundred pounds - and that she always performed seated when singing with her sisters (so, according to bel canto singing technique, running the risk of restricting her breathing) ${ }^{30}$ But Connie also shared a further impairment with a number of her most distinguished peers, those who together with her established the ground rules of the American Songbook style - 
Bing Crosby, Ethel Waters, Louis Armstrong. They all had nodules on the vocal folds, an occupational hazard for the popular singer and the cause of anything from mild hoarseness to extreme gruffness or even complete loss of the voice. ${ }^{32}$ I have written about this issue elsewhere (Stras 2006); suffice to say here that the signs of vocal damage, the traces of wear and tear that the body develops in the course of a life, are accepted far more easily in jazz than in classical singing. Indeed, what is disabling in one repertoire is positively enabling in the other, for these signs of body in the voice assure the audience on a subliminal level that they are hearing authenticity from the performer, so again inviting identification and promoting acceptance. Moreover, the personal history of the performer can have a bearing on how the voice is heard and 'read'; for example, even very early in Connie's solo career she was praised for the 'feeling and beauty in her voice, the kind only suffering and tragedy can impart' (Meise 1931).

Our understanding of jazz and popular music has been enormously enriched by the critiques offered by race studies and gender studies, as we seek to understand how cultural discourses of difference shape and influence all aspects of our lives, even when distant or completely separated from their biological origins. However, our relationship with disability - as a concept, as a reality, and even as a discourse - is fundamentally on another level than our relationship with race or gender. We presume our bodies cannot spontaneously mutate into another sex or race, so in any process of identification whereby we recognise and understand the Other so that we may better know ourselves, we negotiate physical boundaries through the intellect - and we do this from an assumed position of genetic stability. ${ }^{32}$ Disability, on the other hand, is an ever-present possibility, an uneasy (and, ultimately - if one lives that long - inevitable) alternative future for anyone who considers him- or herself non-disabled. Those cultural forms that interrogate or challenge assumptions regarding what's normal and what's not, that allow people to engage and identify with, and possibly even embrace abnormality without threat, work to alleviate both the anxiety of the non-disabled and the alienation of the disabled. The jazz or pop singer has a privileged and vital role in this process, as an agent through whom identification becomes easier, less intellectual or abstract, more corporeal. Jazz may once have been disabled music - music that was functionally and aesthetically impaired - to many who found its unboundedness uncomfortable and its language incomprehensible. The singer's voice, however, produced and reproduced so that its bodily source was unmistakably heard, validated jazz as an expression of human experience. The Boswell Sisters, and Connie Boswell in particular, were key figures in the development of the voice as a carrier for jazz; they clearly also had a unique understanding of the relationship between 'normal' and 'abnormal' in music, as in their daily lives. They are certainly not the only artists whose music challenged boundaries, but their history, reception and the comprehensive record of their work allows a privileged examination of how the unacceptable became acceptable, and how what was once considered not fit for purpose could eventually become a 'standard of entertainment' and the inspiration for so much that followed after them.

\section{Acknowledgements}

My thanks to the anonymous reader, Joseph Straus and Neil Lerner for their comments on an earlier version of this text, to Jason Koransky, editor of Down Beat, 
and to Cynthia Lucas, David McCain, Randall Riley and the inestimable members of the discussion forum on http://www.bozzies.com for their generosity in making materials available and allowing me to try many unlikely ideas in their midst.

\section{Copyright acknowledgements}

'Yes Sir, That's my Baby', Words by Gus Kahn, Music by Walter Donaldson, (c) 1925 Bourne Co and Donaldson Publishing Co, USA, EMI Music Publishing Ltd, London W8 5SW, Reproduced by permission of International Music Publications Ltd (a trading name of Faber Music Ltd). All Rights Reserved.

'Everybody Loves my Baby, But my Baby Don't Love Nobody but Me', Words and Music by Jack Palmer and Spencer Williams, (50\%) (C) 1924 Redwood Music Ltd, London NW1 8BD and Warner/Chappell Music Ltd, London W6 8BS, (50\%) (C 1924 B. Feldman \& Co Ltd, London W8 5SW, Reproduced by permission of Faber Music Ltd and International Music Publications Ltd (a trading name of Faber Music Ltd). All Rights Reserved.

'Was That the Human Thing to Do?', Words by Joseph Young, Music by Sammy Fain, (C) 1931 Witmark-M-Sons and Warock Corporation, USA, B. Feldman \& Co Ltd, London W8 5SW, Reproduced by permission of International Music Publications Ltd (a trading name of Faber Music Ltd). All Rights Reserved.

\section{Endnotes}

1. Connie changed the spelling of her name to 'Connee' a few years after embarking on her solo career; various reasons have been put forward for this change, including that she found it difficult and tiring to dot the ' $i$ ' when signing autographs, as her right hand and arm were weakened by polio. Family sources maintain that her sister Martha persuaded her to make the change 'for good luck'. As this essay refers to her singing in both phases of her career, I shall retain the original spelling.

2. A key article published in Down Beat during the middle of Connie's career shows how she was regarded by her peers (Lucas 1944). Bing Crosby's relationship and collaboration with Connie is discussed by Gary Giddins (2001); Ella Fitzgerald's fundamental debt to her is related in many Fitzgerald biographies, notably that by Stuart Nicholson (1996).

3. Personal interview, Vet 'Chica' Boswell Minnerly, October 2002.

4. Between the two, the middle way - the biopsychosocial model - proposes that disability is an 'outcome of interactions between health conditions (diseases, disorders and injuries) and contextual [environmental and personal] factors ... Disability therefore involves dysfunctioning at one or more of these ... levels: impairments, activity limitations and participation restrictions', where impairments are 'problems in body function or structure such as a significant deviation or loss' (World Health Organization 2002, p. 10).

5. 'I omit all mention of the Negro's bewildering contribution to the music of today - Jazz owing to my uncertainty as to whether it has a civilising or decivilising influence. Perhaps the spirit from which it has been born has been warped in the process. If so, I trust that, like the child's, its rickets may be curable' (Guggisberg and Fraser 1929, p. 32).

6. More examples can be found in Chapter 5, 'Prudes and primitives', of Kathy Ogren's The Jazz Revolution: Twenties America and the Meaning of Jazz (1989, pp. 139-61).

7. Middlesborough Daily News, Kentucky, 22 July 1931: 'CHARGE PLAYER IS INSANE / Because an age [sic] woman here revels in playing jazz music on her radio in the early morning hours, neighbors, who claim they are kept awake, have demanded that she be subjected to a sanity test'.

8. Traverse City Record-Eagle, Michigan, 20 May 1926. 'JAZZ LIFE MAY MEAN CRIPPLES / Obstetrics expert speaks / Atlantic City, N.J. May 20 / Joy riding, gay parties and intemperate dancing which characterize the era of "jazz mania," may be paid for in deformed children, delegates to the National Health Congress were told today. / Dr Fred A Adair, professor of obstetrics at the medical school of the University of Minnesota, told the convention that pre-natal deaths and the birth of children suffering from serious deformities may sometimes be the result of expectant mothers carrying to an extreme their indulgence in gayeties. 
He urged prospective mothers to lead wellordered lives'.

9. Lima News, Ohio, 22 June 1925 [Syndicated story] 'ACTRESS SAYS JAZZ DEFORMS GIRLS' LEGS / Too Much Syncopation Destroys Graceful Curves and Leaves Imprint on Knees and Feet - Advocates Classical Dancing as Remedy / NEW YORK, June 00 (Special) - Jazz has been blamed for practically every evil since the war, and now comes a new accusation. / "It is ruining the legs of the American girls," says Peggy Fortune, motion picture actress whose perfectly formed legs caused Florenz Ziegfeld to choose her for a place in the Follies chorus of "Pretty Ladies," a new picture which has the first beauty chorus in the films. / She says that nearly 90 per cent of the girls of this country have imperfect legs. / "Altho the American ankle may be trim and shapely," the fair Peggy says, "the leg as a whole is losing its perfection and becoming distorted in shape, and this is the reason - jazz dancing has a tendency to make bulging and knocked knees, because so much of it is done with the knees bent. / BECOME SLOUCHY / "Instead of the grace, ease and poise the figure acquires thru classic dancing, a slouch and an ungraceful carriage is the result of too much syncopation." / She believes this also injures the arch of the foot and destroys the graceful curves of the leg. / The perfection of her own legs is the direct result of avoiding jazz dancing, and sticking to the classical type, Miss Fortune says. "Classic dancing," she says, "not only helps to keep the legs trim, but corrects imperfections and helps develop a graceful carriage and perfect figure"'.

10. Fort Wayne News and Sentinel, Indiana, 14 August 1920 [Syndicated column]: "'Health Matters" by William Brady, MD, Noted Physician and Author': 'The very music of the modern dance is indecent. It has come by degrees, this jazz music and the rotten style of dancing which goes with it ... Dancing is a wholesome pastime and a pretty thing to look at. There is nothing objectionable in polite forms of dancing, at least form the viewpoint of hygiene. But these impolite, questionable, licentious dances accompanied with jazz music are ruinous to health in a great many instances, because they break down the moral restraints and lead to deplorable disasters. / Even if the young man indulging in jazz dancing is morally impeccable, he suffers, nevertheless, a physical injury which becomes apparent enough and often brings him to the physician for treatment. No doubt the upright young woman who acquires the habit of jazz suffers greater injuries - and the disturbances which follow are readily misinterpreted by women who undertake to advise her. / The irregular hours, the loss of sleep, the foul atmosphere of the dance hall or cabaret, the intimate contact with persons harboring all sorts of disease, these are rather unimportant features of the unhygienic jazz.
The demoralization of young men and women which this lecherous importation is working cannot fail to lower the respect of the male sex, for the female sex, and heaven knows too, many men consider the sex of their mother legitimate prey to lust as it is'.

11. Anne Shaw Faulkner, 'Does jazz put the sin in syncopation?', The Ladies' Home Journal, August 1921, pp. 16, 34; reprinted in Walser (1999).

12. Moberley Monitor, Missouri, 9 May 1921: 'This is bad music, but the difference between the incantation crazed fanatics and the patriot or soldier stirred to noble action by music is a difference in the music itself. Jazz is compounded after the same formulas as the Voodoo chants. Typifying the unbalanced state of humanity's mind, it tends to unhinge it more and more. Human nerve tissues despond to this perverted organization of sound just as readily as did those of the Voodoo zealots, and just as readily will they respond to music of the higher, ennobling order. The world needs good music as never before'.

13. 'Where is jazz leading America?', The Etude, August 1924, pp. 517-18, 520, and September 1924, p. 595; reprinted in Walser (1999).

14. Rosemarie Garland-Thomson considers this transformation as beginning in the US in the antebellum period when compensation for both industrial and combat injuries was instituted, and persisting until the Disabilities Act of 1990 (Garland-Thomson 2007, pp. 46-51). The disabled bodies and shattered minds of soldiers and veterans were also increasingly on display in films made immediately post-World War I and throughout the 1920s, though curiously not predominantly in explicit combat dramas. Instead, 'the war was displaced aesthetically into comedy, adventure, drama, the western, the romance and ... the horror genre' (Randell 2003, p. 37). Karen Randell observes with reference to horror, 'so [Lon] Chaney's films, which offer us a visual representation of mutilation, deformity and disfigurement, become part of an already circulating discourse concerning the return of disabled veterans whose physical and emotional scars become more apparent as the decade progresses. These films re-locate and re-signify the war experience of the injured soldier: deformity and disfigurement, as it appears in the suspense/ horror films of Lon Chaney, become a site of fascination and spectacle for the audience' (ibid., p. 113).

15. The seeming pre-occupation with 'nervous disorders' may also reflect the phenomenon of shell-shock and other mental conditions affecting many returning veterans. Between eight and fifteen per cent of veterans were diagnosed with " shell shock," "nervous disorder," "neurasthenia," and "psycho-neurosis"', to the extent that they were considered unemployable in their previous peace-time occupations, and therefore encouraged to undergo 
re-training, albeit frequently unsuccessfully (Gelber 2005, p. 168).

16. Connie related the letter slightly differently in an interview with Rich Conaty: 'I have a letter now that I wouldn't give up for anything, from a woman who wrote to us when we were performing (on the air) in San Francisco, and we were doing all this weird stuff ... She wrote to the station and said, "Please get those terrible Boswell Sisters off the station! You can't follow the melody and the beat is going too rapidly," and then she said, "And to me they sound like savage chanters!"'.

17. Bing Crosby coined his own words to describe arrangements according to Kapp's criteria: a 'Kappastrophe' would not sell, but if a tune were 'Kapphappy' it would be a certain hit (Giddins 2001, p. 391).

18. Popular Songs, 1/4 (1935), p. 22.

19. For example, the Carlyle Cousins, a British group of 'Boswell emulators' are reviewed performing in London in 1933, a month before the Boswells themselves first opened at the Palladium; their performance contained 'nothing unduly hot or too advanced for ordinary tastes. Nevertheless, the result was entirely excellent, the Cousins putting over a programme which was an ideal blend of the interesting and the commercial ... [and] if unconventional, came near to being perfect for the purposes of variety'; Melody Maker, 3 June 1933, p. 13. Note that 'commercial' here has a pejorative context - the Melody Maker was among the organs of a crusade promoting jazz as legitimate art music (Scott 2003, p. 89).

20. Will Friedwald maintains that the Boswells were never superseded as the finest jazz vocal group of their kind: 'Too bad no group came along to succeed the Boswells as succinctly as the Bozzies took up where the Rhythm Boys left off. Too bad that in the fifty years since then no group has ever replaced them or beat them at what they did best. Too bad that the swing era couldn't inspire vocal groups as meaningful as its big bands and solo singers' (Friedwald 1996, p. 173). James Von Schilling argues that the Boswells' true legacy as a group was to instrumental music, claiming their arrangements and voicings were hugely influential on arrangers/bandleaders such as Glenn Miller and Artie Shaw (Von Schilling 2008, p. 198).

21. Novelty was indeed an important aspect of the marketing of jazz in the 1920s. Ryan Jerving describes commercial jazz as 'a New World form shot through with the accents of a transnational America, accents whose dissonance within the imagined nation had troubled the would-be 100 percent Anglo-Saxonist harmony of 1920s nativism ... This dissonance, [was not] something distinct from the commercial mainstream, [but] something inherent to it, a modernist effect generated and sustained by the make-it-new imperative that drove the entertainment industry's cycle of innovation - novelty - and planned obsolescence. / For the post-Great War decade, jazz had resonated as a style in which transnational ethnicity and mass-mediated novelty could intersect to unsettle standard ideas of American national identity and the language through which it was being imagined' (Jerving 2003, pp. 239-40). The ethnic impropriety of the Boswells' music, inasmuch as it reflected 'blackness' also contributed to its novelty (Stras 2007). But blackness in itself, whether biological or musical, might be considered 'freakish' and therefore aligned with disability: Garland-Thomson notes that at American freak shows of the late nineteenth and early twentieth centuries, 'the two main types of people presented as freaks were "normal" non-Westerners and "abnormal" Westerners ... Hence a nondisabled person of color billed as the "Fiji Cannibal" was equivalent to a physically disabled, Euro-American called the "Legless Wonder"' (Garland-Thomson 1997, p. 63).

22. The Boswell Sisters' treatment of the song, together with a solo version by Connie, can be compared directly with others by the Mills Brothers and Bing Crosby on 'Gems From "George White's Scandals"' - all versions appear in a medley on the disc. For a chronicle of popular song as a manifestation of and a reaction to the Depression, see Arnold Shaw's Let's Dance: Popular Music in the 1930s (1998, passim). For an alternative view, see Lewis Erenberg's Swingin' the Dream: Big Band Jazz and the Rebirth of American Culture (Erenberg 1998, pp. 19-32).

23. It was released on the flip side of 'Stop the Sun, Stop the Moon', a newly published song, which was the other track recorded at the session. Given that both 'Everybody Loves my Baby' and 'Yes, Sir, That's my Baby' were hits in 1925, we might assume that this arrangement was a Boswell 'classic', devised and perfected during their earlier years in vaudeville.

24. Incidentally, this device also renders the song gender-neutral; although other female singers - including Alberta Hunter, Clementine Smith and Lee Morse - had recorded versions of the song since the mid-1920s, they all used their own lyrics (some salacious) to replace 'She's got a form like Venus, honest, I ain't talking Greek / No one can come between us, she's my Sheba, I'm her sheik'. The Boswells maintained a very upright image, appropriate to wellbrought-up southern white women; the double-entendre so familiar to 1920 s vaudeville audiences had little or no part in their act.

25. The sentimental mode 'presents disability as a problem to be solved, an obstacle to be eliminated, a challenge to be met. Such a logic transforms disability from an attribute of the disabled person to a project that morally enables the rescuer' (Garland-Thomson 2001, p. 355).

26. 'Boswellese' began as a private childhood play language for the sisters. It features as a novelty 
rhythmic device on a number of their recordings, including 'It Don't Mean a Thing (If it Ain't Got that Swing)'; here, in 'Yes, Sir, That's my Baby', it creates a banjo-strum rhythm. It is perhaps worth noting that play languages such as gibberish or Pig Latin are devices used by children to set boundaries for inclusion and exclusion.

27. Moreover, the link, in the mind of the late 1920s audience, between the white girl singer and 'baby talk' scat had been well established by Helen Kane's 'boop-a-doop' styling; and it is evident in early reviews of the Boswells, if not actually in the performances. The reviewer Rufus of The Phonograph Monthly Review identifies 'remarkable ... boops' in the Boswells' 'Heebie Jeebies' (where there is scat, but no 'boops') and 'baby-voiced harmonizations' in 'Whad'ja Do to Me?' and 'When I Take my Sugar to Tea', two performances that might be considered relatively muscular: ('Rufus' 1930, 1931).

28. A review of 'It Don't Mean a Thing (If it Ain't Got that Swing)' (see n. 26 above) reflects this sense of a song undergoing metamorphoses into something irredeemably, but irresistibly, other: 'I have rarely enjoyed a record by the THE BOSWELL SISTERS so much as I have It Don't Mean a Thing and Minnie The Moocher's Wedding Day (Brunswick 1436). The first title is far and away the one I have liked best in years. Connie's grand solo singing of the number leaves no doubt as to the truth of the title, but I defy anyone to understand a word of what the girls sing in the second chorus. They seem to be inventing a language entirely their own; it sounds like English written upside down and sung backwards. Most odd. I will not give away the secret of what Tom Dorsey does to the tune when he plays it. Get the record and see if his solo is not the sweetest thing you have heard even from him. A record of three moods in which the tune suffers one key-change into something very rich and strange' ('Mike' 1933).

29. Vallee also sought to emulate instrumental technique in his singing, with particular reference to vibrato. He "adapted the "live vibration" he could make with his saxophone to his vocal instrument, and found that it was particularly effective in conveying emotional involvement' (McCracken 1999, p. 376)

30. As she was never photographed standing, it is difficult to ascertain her true height and weight, but her petite build was widely reported in the popular media of the 1930s. She did, however, have a special stool built so that she could appear to perform standing; it glided across the floor on ball-bearings, and she would be escorted to her performance position by an emcee. Slight pressure on her hand would set the stool in motion, and she could even perform dance routines with it, kicking her feet to simulate dance steps.

31. I have begun an examination of the 'problem' of the aesthetic valuing of hoarseness in classical and popular genres in a chapter in Sounding Off: Theorizing Disability in Music. Armstrong reportedly developed nodules as a child, hawking newspapers on the streets of New Orleans; Crosby's developed during his early career. Both Waters and Connie had surgery to remove their nodules, Connie when she was a teenager, and Waters when she was at the height of her popularity (Stras 2006, pp. 17980).

32. 'That anyone can become disabled at any time makes disability more fluid, and perhaps more threatening, to those who identify themselves as normates than such seemingly more stable marginal identities as femaleness, blackness, or nondominant ethnic identities' (GarlandThomson 1997, p. 14).

\section{References}

Bakhtin, M. 1981. The Dialogic Imagination, ed. M. Holquist, trans. C. Emerson and M. Holquist (Austin, University of Texas)

Crystal, D. 1990. 'Linguistic strangeness', in On Strangeness, ed. M. Bridges (Tübingen, Gunter Narr Verlag), pp. 13-24

Friedwald, W. 1996. Jazz Singing: America's Great Voices from Bessie Smith to Bebop and Beyond (New York, Da Capo)

Erenberg, L.A. 1998. Swingin' the Dream: Big Band Jazz and the Rebirth of American Culture (Chicago, University of Chicago)

Garland-Thomson, R. 1997. Extraordinary Bodies: Figuring Physical Disability in American Culture and Literature (New York, Columbia University)

2001. 'Seeing the Disabled: visual rhetorics of disability in popular photography', in The New Disability History: American Perspectives, ed. P.K. Longmore and L. Umansky (New York, New York University), pp. 335-74

Gelber, S. 2005. 'A "hard-boiled order": the re-education of disabled WWI veterans in New York City', Journal of Social History, 39, pp. 161-80

Giddins, G. 2001. Bing Crosby: A Pocketful Of Dreams: The Early Years, 1903-1940 (Boston, New York and London, Little, Brown \& Co.)

Guggisberg, G., and Fraser, A.G. 1929. The Future of the Negro: Some Chapters in the Development of a Race (London, Student Christian Movement Press)

Jerving, R. 2003. 'Jazz language and ethnic novelty', Modernism/modernity, 10, pp. 239-68 
Leonard, N. 1964. Jazz and the White Americans: The Acceptance of a New Art Form (London, Jazz Book Club)

Lerner, N., and Straus, J. (eds.) 2006. Sounding Off: Theorizing Disability in Music (New York, Taylor and Francis)

Lockheart, P. 2003. 'A history of early microphone singing, 1925-1939: American mainstream popular singing at the advent of electronic microphone amplification', Popular Music and Society, 26, pp. 367-85

Longmore, P.K., and Umansky, L. 2001. 'Disability History: from the margins to the mainstream', in The New Disability History: American Perspectives, ed. P.K. Longmore and L. Umansky (New York, New York University Press), pp. 1-29

Lucas, J. 1944. 'Cats hepped by Connee's chirping', in Down Beat, pp. 3-4

McCain, D. 2001. Liner notes to Boswell Sisters Collection, Volume 5, Nostalgia Arts NOCD 3023

McCracken, A. 1999. "'God's gift to us girls": crooning, gender, and the re-creation of American popular song, 1928-1933', American Music, 17, pp. 365-95

Meise, J.A. 1931. 'Black-outs', New Orleans States, 6 December

'Mike'. 1933. 'Mike's disc-course', Melody Maker, February, pp. 151-7

Nicholson, S. 1996. Ella Fitzgerald (London, Indigo)

Ogren, K. 1989. The Jazz Revolution: Twenties America and the Meaning of Jazz (New York, Oxford University Press)

Randell, K. 2003. Hollywood and War: Trauma in Film After the First World War and the Vietnam War, Ph.D. thesis, University of Southampton

'Rufus'. 1930. 'Analytical notes and reviews', The Phonograph Monthly Review, 5, p. 29 1931. 'Analytical notes and reviews', The Phonograph Monthly Review, 5, p. 252

Scott, D.B. 2003. 'Incongruity and predictability in British dance band music', in From the Erotic to the Demonic: On Critical Musicology (New York, Oxford University Press), pp. 80-100

Shaw, A. 1998. Let's Dance: Popular Music in the 1930s (New York, Oxford University Press)

Stras, L. 2006. 'The Organ of the Soul: voice, damage and affect', in Sounding Off: Theorizing Disability in Music, ed. N. Lerner and J. Straus (New York, Taylor and Francis), pp. 173-84

2007. 'White face, Black voice: race, gender and region in the music of the Boswell Sisters', Journal of the Society for American Music, 1, pp. 207-55

2008. "Who Told You That Lie?": picturing Connie Boswell', in Re-framing Representations of Women: Figuring, Fashioning, Portraiting and Telling in the 'Picturing Women' Project, ed. S. Shifrin (Burlington, VT, Ashgate), pp. 251-67

Straus, J. 2006. 'Normalizing the abnormal: disability in music and music theory', Journal of the American Musicological Society, 59, pp. 113-84

Thomas, C. 1999. Female Forms: Experiencing and Understanding Disability (Buckingham and Philadelphia, University of Michigan)

Von Schilling, J. 2008. 'Hearing the Boswell Sisters', Popular Music and Society, 31, pp. 191-200

Walser, R. (ed.) 1999. Keeping Time: Readings in Jazz History (New York and Oxford, Oxford University Press)

World Health Organization 2002. Towards a Common Language for Functioning, Disability and Health: The International Classification of Functioning, Disability and Health (Geneva, World Health Organisation)

\section{Discography}

The Boswell Sisters, 'Was That the Human Thing to Do?' Brunswick Canada 6257. 1932; re-released on The Boswell Sisters Collection, Vol. 2, Nostalgia Arts 3008. 1999

'Was That the Human Thing to Do?' Brunswick 6257. 1932; re-released on The Boswell Sisters Collection, Vol. 1, Nostalgia Arts 3007. 2000

'Everybody Loves my Baby'. Brunswick 6271. 1932; re-released on The Boswell Sisters Collection, Vol. 1, Nostalgia Arts 3007. 2000

'Everybody Loves my Baby', live performance Schevinegen. 1935; released on Americans in Holland: The Great 1930s, Timeless 86. 2004

'It Don't Mean a Thing (If it Ain't Got that Swing)', Brunswick 6442. 1932; re-released on The Boswell Sisters Collection, Vol. 3, Nostalgia Arts 3009. 2000

Bennie Kreuger and His Orchestra, 'Was That the Human Thing to Do?' Vocal refrain by Frank Sylvano, Brunswick 6246. 1932

Victor Young and his Orchestra, 'Gems From "George White's Scandals"”. Brunswick 20102. 1931; re-released on The Boswell Sisters Collection, Vol. 2, Nostalgia Arts 3008. 1999 